\title{
Development of Liquid Nitrogen Free and Efficient DNA Isolation Method for Plants Rich in Volatile Oil, Secondary Metabolites and Polysaccharides
}

\author{
Manish Kumar Suthar*, V. Thondaiman, Parmeshwar Lal Saran and \\ Manish Kumar Mittal \\ ICAR-Directorate of Medicinal and Aromatic Plants Research, Anand, Gujarat-387310, India \\ *Corresponding author
}

\section{A B S T R A C T}

\section{Keywords}

Medicinal plants, volatile oil, Polysaccharides, DNA isolation, Secondary metabolites

\section{Article Info}

Accepted:

15 November 2019 Available Online:

10 December 2019
Ocimum sanctum L. or "Tulsi" or Holy basil is a plant well known for its medicinal properties. This plant is rich in essential oil sequestered in peltate glands. The Tulsi is rich source of eugenol, methyl eugenol, chavicol, ursolic acid, rosmerinic acid and other phenolics and terpenes. Aloe barbadensis and Plantago ovata are plants rich in polysaccharides. These plants are very important medicinal plants. A. barbadensis is source of aloin which is used in various cosmetic products and $P$. ovata is the main source of Isabgol-Husk. DNA based studies in these and similar plants require optimization of DNA isolation method due to presence of high level of secondary metabolites and polysaccharides. Which generally hamper all downstream enzymatic analysis like PCR amplification. DNA isolated using standard DNA isolation method especially from stored leaves from such plants is not suitable for downstream enzymatic analysis like PCR. In present study, a DNA isolation method has been developed which results in high quality and intact DNA from Tulsi, A. barbadensis and $P$. ovata. This method is free from the use of liquid nitrogen, Phenol, and Cetyltrimethyl ammonium bromide and moreover efficient to isolate intact DNA which can be easily used for downstream molecular analysis. DNA isolated by newly developed method was successfully amplified by PCR reaction using random and specific primers.

\section{Introduction}

Isolation of pure and high-quality DNA from plants is crucial step towards molecular biological studies. DNA isolation process requires costly reagents and instrumentation. However, high levels of secondary metabolites and polysaccharides affect the purity and quality of isolated DNA. Generally, the DNA isolation protocol is to be developed or modified according to different plant species having different metabolites. Holy basil or Ocimum sanctum L. (O. tenuiflorum) is a sacred plant of India and belongs to 
Lamiaceae family. This herb is also known as "Tulsi", "The Queen of herbs" and "The Mother Medicine of Nature" (Singh and Hoette, 2002). O. sanctum has been indicated as anti-microbial, anti-spasmodic, antidiabetic, anti-cancer and anti-fertility agent (Pattanayak et al., 2010). The chemical composition of different varieties or accessions of $O$. sanctum is very complex having various phytochemicals in different proportions.

All herbage parts of this species have high level of secondary metabolites. Specifically, the leaves have peltate glands and other glandular structures which synthesise volatile oils containing eugenol, chavicol, methyl eugenol, ursolic acid, caryophyllene, methyl chavicoletc (Kelm et al., 2010; Shishodia et al., 2003; Iijima et al., 2004). These metabolites affects the quality of DNA isolated from $O$. sanctum. At present, commercially available kits for DNA isolation or purifications seems the only source for high quality DNA purification. This is also evident in the genomic DNA isolation methodologies used for $O$. sanctum in recent reports (Rastogi et al., 2015; Upadhyay et al., 2015). But use of such kits increases cost of studies. Similarly, DNA isolation from some plant species rich in polysaccharide like Aloe barbadensis and Plantago ovata using CTAB methods and commercially kits is very difficult. Such species give sticky DNA samples which cannot be used for PCR amplifications. There are no single DNA isolation method which can universally be used to isolate DNA from $O$. sanctum, $A$. barbadensis and $P$. ovata. In present study, we have developed a methodology for the isolation of high-quality DNA from $O$. sanctum, $A$. barbadensis and $P$. ovata amenable to be used in further downstream molecular studies. This newly developed methodology is a cost effective as it eliminates use of CTAB, phenol and liquid nitrogen, rapid and also equally effective in fresh as well as stored leaves. This methodology may be useful in other plant species having high level of contaminating metabolites and polysaccharides in affordable manner.

\section{Materials and Methods}

\section{Plant samples and DNA isolation}

Four different accessions of $O$. sanctum species were used to isolate the DNA (Fig. 1). These different accessions have different degree of phytochemical present. Some accessions have comparative high level of volatile oils and peltate gland and some are known to have different terpenes and phenylpropanoids. These plants were grown in field and leaves were harvested and stored for one year in minus 80 deep freezer. Further, DNA was also isolated from two polysaccharide rich crops Aloe barbadensis and Plantago ovate.

Modified CTAB method: This method was based on method given by Doyle and Doyle (1990) with some modification.

300-400 mg leaf sample was ground in liquid nitrogen in $800 \mu \mathrm{l}$ of $4 \%$ CTAB extraction buffer $(100 \mathrm{mM}$ Tris-HCl, $1.4 \mathrm{M} \mathrm{NaCl}, 20$ $\mathrm{mM}$ EDTA with $4 \%$ CTAB) containing PVP (up 2\%).

Samples were incubated at $64{ }^{\circ} \mathrm{C}$ for $1 \mathrm{hr}$ with mixing after each 15 min. intervals.

Centrifuged at $12,000 \times \mathrm{g}$ for $5 \mathrm{~min}$. and supernatant was collected.

RNase A was added and incubated at $37^{\circ} \mathrm{C}$ for $20 \mathrm{~min}$.

Equal volume of chloroform:isoamylalcohol (C:I) $(24: 1)$ or P:C:I (25:24:1) was added. 
Emulsions were centrifuged for $15 \mathrm{~min}$. at $14,000 \times \mathrm{g}$.

The aqueous supernatants were transferred to separate tubes and repeated the same step.

In aqueous supernatants, ice cold isopropanol was added and mixed gently.

Incubation at minus $20{ }^{\circ} \mathrm{C}$ was given overnight.

Samples were centrifuged for $14,000 \times \mathrm{g}$ for $10 \mathrm{~min}$.

Pellets were washed with $70 \%$ alcohol by spinning at $12,000 \times \mathrm{g}$ for $8 \mathrm{~min}$.

The pellets were air dried until complete loss of alcohol smell. Finally, air dried pellets were suspended in molecular biology grade water. CTAB method followed by purification by Kit: DNA isolated by above method was taken as starting material for the kit supplied by thermo scientific (GeneJET Plant Genomic DNA Purification Kit). Finally, DNA was eluted in elution solution supplied with kit.

\section{Our Methods}

Prepare extraction buffer (sucrose $(0.5 \mathrm{M})$, Tris $(150 \mathrm{mM}), \mathrm{NaCl}(1 \mathrm{M})$, EDTA $(40 \mathrm{mM})$, TritonX100 (2\%) and BME (2.5\%).

Grind 200-300 mg leaves samples in extraction buffer (having a pinch of PVP).

Incubate suspended material at $60{ }^{\circ} \mathrm{C}$ for 30 $\min$.

Centrifuge at $12,000 \times \mathrm{g}$ for $10 \mathrm{~min}$ and discard supernatants.

Suspend the pellets in lysis buffer contain $2 \%$ SDS, $120 \mathrm{mM}$ Tris, $20 \mathrm{mM}$ EDTA, $1.4 \mathrm{M}$ $\mathrm{NaCl}$ and $1 \% \mathrm{BME}$.
Mix the suspension and incubate at $64{ }^{\circ} \mathrm{C}$ for 45 min.

Centrifuge for $12,000 \times \mathrm{g}$ for $12 \mathrm{~min}$.

Collect the supernatants and add equal amount of C:I.

Mix the sample to form emulsion and centrifuge for $14,000 \times \mathrm{g}$ for $15 \mathrm{~min}$.

Collect upper clear aqueous layer and add $1 / 10$ volume of $3 \mathrm{M}$ sodium acetate ( $\mathrm{pH}$ 5.2).

After mixing, add $2 / 3$ volume of ice-cold isopropanol and mix gently.

Incubate at minus $20^{\circ} \mathrm{C}$ for $1 \mathrm{hr}$.

Centrifuge at $14,000 \times$ gfor $10 \mathrm{~min}$.

Wash the pellets with $70 \%$ alcohol solution by centrifuging at $12,000 \times \mathrm{g}$ for $8 \mathrm{~min}$.

Air dry the pellets and dissolve in molecular grade water.

These DNA solutions were directly used in PCR or RNA was removed as described above. Genomic DNA samples were analysed using $0.8 \%$ agarose gel electrophoresis. Quantitative estimations of all DNA samples were performed by Nano Drop spectrophotometer.

\section{PCR amplification}

DNA isolated was subjected to PCR amplification. $50 \mathrm{ng}$ DNA was PCR amplified using both gene specific primers and primers developed for SSR in $O$. sanctum (unpublished). For gene specific primer amplification, the PCR cycles were as: $94{ }^{\circ} \mathrm{C}$ for 4 min., 35 cycles of $94{ }^{\circ} \mathrm{C}$ for $45 \mathrm{sec}$., 54.5 ${ }^{\circ} \mathrm{C}$ for 45 sec., $72{ }^{\circ} \mathrm{C}$ for 55 sec., followed by final extension of $72{ }^{\circ} \mathrm{C}$ for $7 \mathrm{~min}$. For SSR primers the annealing temperature was $53{ }^{\circ} \mathrm{C}$ 
and remaining protocols were same with minor variations. A. barabadensis and $P$. ovata DNA isolated using newly developed method was amplified using primers designed for SRAP marker analysis (primers: Me1+Em6 and Me2 +Em6) and PCR cycles defined for SRAP analysis (Bhatt et al., 2017). PCR amplified products were analysed by 1.2 $\%$ agarose gel with ethidium bromide.

\section{Results and Discussion}

Pure and high-quality DNA is starting point for any DNA based molecular study. Secondary metabolites form complexes with DNA which hinders the downstream enzymatic reactions. The use of CTAB and liquid nitrogen generally has their own limitations. CTAB method requires fresh preparations each time as CTAB buffer cannot be stored for long time. Second, liquid nitrogen is not available easily in developing countries but these are main hot spots for medicinal plants. Phenol also associated with its own corrosive nature. Overall, there is always a need to develop a method which is free from all above limitations. Agarose gel electrophoresis of isolated DNA from Ocimum sanctumis shown in Figure 2a. Intensity of bands and absence of smearing indicated that sufficient and intact DNA was isolated using all three methods used in present study. Table 1 shows quantitative estimation of isolated DNA samples. The quantitative estimation suggested that all used methods seem equally efficient to isolate DNA from the accessions of different chemical compositions. After diluting the $O$. sanctum DNA samples (50 ng/ $\mu$ l) PCR amplifications were carried out and results of amplifications are shown in Figure 2b. Interestingly, despite the good quantity and intact nature all DNA isolated from all methods used, DNA isolated from $O$. sanctum using CTAB alone failed to amplify gene specific and SSR primers. But DNA isolated by CTAB method followed by purification by kits resulted in to amplifications. These results indicated that some interfering metabolites may be present in DNA which may form complex with DNA and limits the enzymatic reactions. Even after the purification with P:C:I isolated DNA failed to give PCR amplification. Use of kits for further purification of DNA may eliminate these interfering molecules. But contrasting results were obtained when DNA was isolated with SDS based methods. Regardless of chemically different accessions used in the study our new method resulted in to amplification in all samples.

Table.1 DNA quantitative and qualitative analysis

\begin{tabular}{|c|c|c|c|c|c|c|}
\hline Plants & \multicolumn{2}{|c|}{ CTAB method } & \multicolumn{2}{c|}{ CTAB followed by Kit } & \multicolumn{2}{c|}{ Newly developed Method } \\
\hline & $\begin{array}{c}260 / 280 \\
\text { ratio }\end{array}$ & $\begin{array}{c}\text { Yield } \\
(\mu \mathrm{g} / \mathrm{g} \text { of } \\
\text { plant })\end{array}$ & $\begin{array}{c}260 / 280 \\
\text { ratio }\end{array}$ & $\begin{array}{c}\text { Yield } \\
(\mu \mathrm{g} / \mathrm{g} \\
\text { plant) }\end{array}$ & $\begin{array}{c}260 / 280 \\
\text { ratio }\end{array}$ & $\begin{array}{c}\text { Yield } \\
(\mu \mathrm{g} / \mathrm{g} \text { plant) }\end{array}$ \\
\hline O. sanctum accession 1 & 1.78 & 255 & 1.85 & 52 & 1.89 & 110 \\
\hline O. sanctum accession 2 & 1.76 & 285 & 1.86 & 64.5 & 1.90 & 135 \\
\hline O. sanctum accession 3 & 1.69 & 205 & 1.84 & 59 & 1.87 & 115 \\
\hline O. sanctum accession 4 & 1.81 & 265 & 1.88 & 75 & 1.88 & 145 \\
\hline Aloe barbadensis & 1.81 & 135 & - & - & 1.91 & 130 \\
\hline Plantago ovata & 1.84 & 155 & - & - & 1.90 & 155 \\
\hline
\end{tabular}


Fig.1 Abaxial and adaxial surfaces of different accessions of $O$. sanctum used in present study.

A. Rich in peltate glands, B: Lowest in peltate gland, C: High phenolic content and D: High pigment content

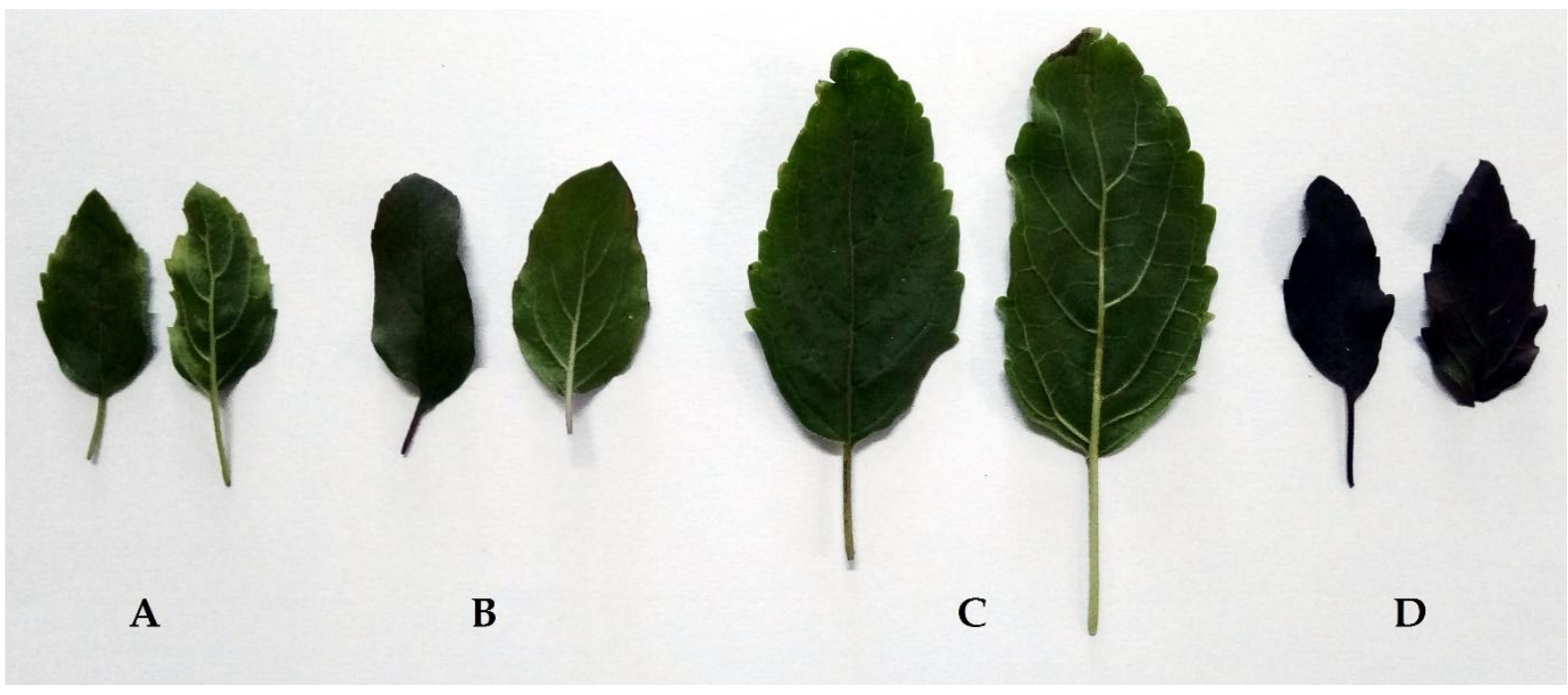

Fig.2 A. $0.8 \%$ agarose gel electrophoresis of isolated DNA from $O$. sanctum samples. A: DNA isolated using CTAB method, B: DNA isolated using CTAB method and purified by Kit, C: DNA isolated newly developed method. b. $1.2 \%$ agarose analysis of PCR amplified DNA of $O$. sanctum. A: PCR amplification of DNA isolated by CTAB method with gene SSR primers (lane 1 to 4 ) and gene specific primers (lane 5 to 8), B: PCR amplification (SSR primers) of DNA isolated by CTAB method and purified by kit (lane 1 to 4 ) and newly developed method (lane 5 to 8), C: PCR amplification of DNA isolated by newly developed method and gene specific primers. M represents $100 \mathrm{bp}$ DNA ladder

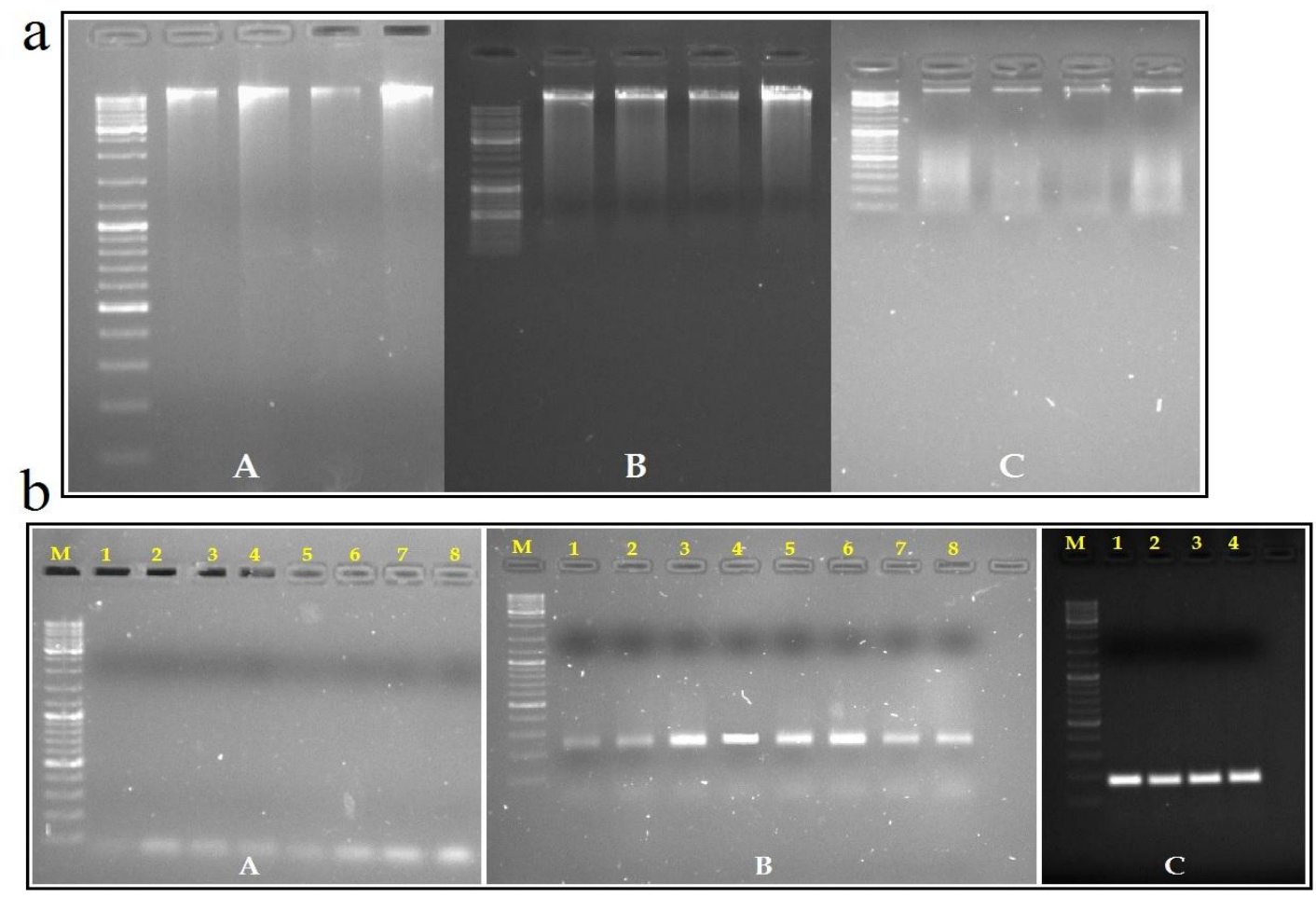


Fig.3 A. $0.8 \%$ agarose gel analysis of $A$. barbadensis and $P$. ovata DNA. Lane 1 represents DNA ladder (100 bp), lane 2 and 3 show DNA isolated from using CTAB method from $A$. barbadensis and $P$. ovata respectively and lane 4 and 5 show DNA isolated using newly developed method from $A$. barbadensis and $P$. ovata respectively. B. $1.2 \%$ agarose electrophoresis of PCR amplified DNA of A. barbadensis and P. ovata DNA using SRAP markers. Lane 1 shows 100 bp DNA ladder, lane 2 and 3 show Me1+Em6 amplification from $A$. barbadensis and $P$. ovata respectively and lane 4 and 5 show Me2+Em6 amplification from $A$. barbadensis and $P$. ovata respectively

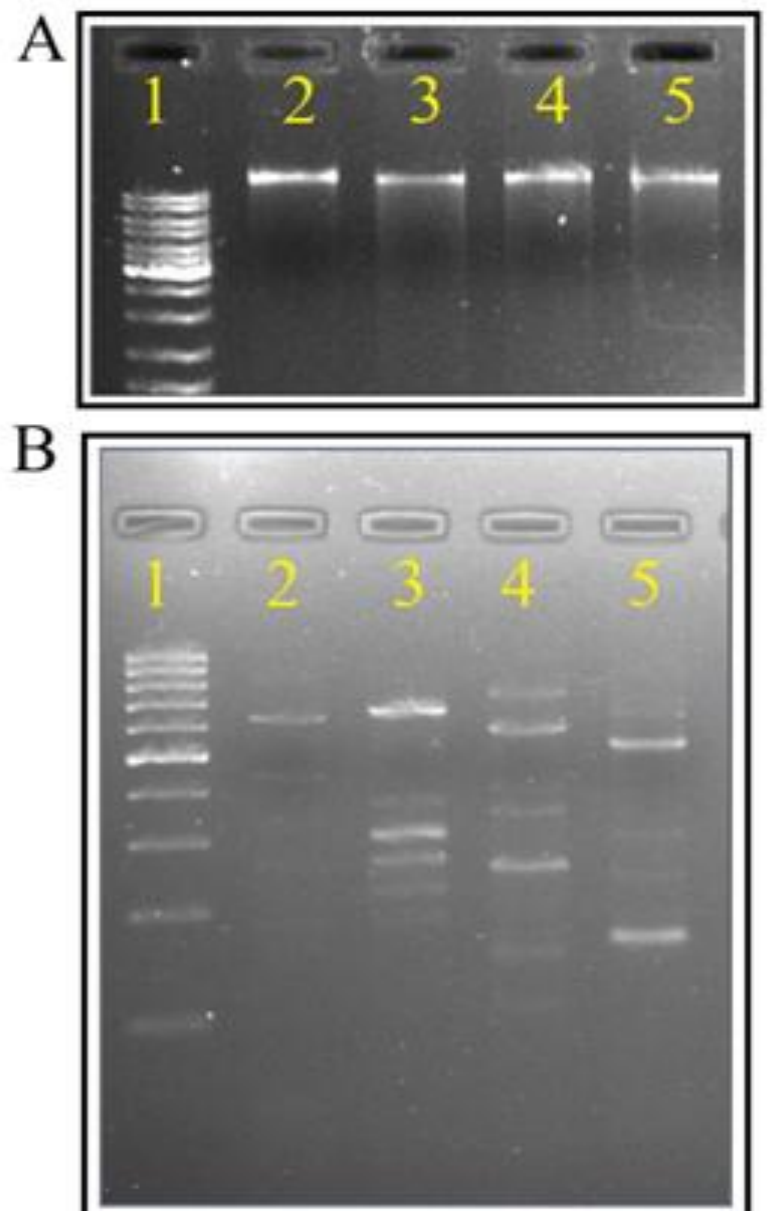

The newly developed method is cost effective, rapid and efficient method for the intact and high-quality DNA isolation from the plants which are rich in volatile oils and secondary metabolites. This method does not require CTAB, costly liquid nitrogen and hazardous phenol. Also, above method is equally effective for plant leaves having high degree of polysaccharides.

\section{Acknowledgments}

We thank ICAR-DMAPR, India for the financial support.

\section{References}

Bhatt, J., Kumar, S., Patel, S. and Solanki, R. (2017) Sequence-related amplified 
polymorphism (SRAP) markers based genetic diversity analysis of cumin genotypes. Annals of Agrarian Science. 15: 434-438.

Doyle, J.J. and Doyle, J.L. (1990) Isolation of plant DNA from fresh tissue. Focus. 12: $13-15$.

Iijima, Y., Gang, D.R., Fridman, E., Lewinsohn, E. and Pichersky, E. (2004) Characterization of geraniol synthase from the peltate glands of sweet basil. Plant Physiology. 134: 370-379.

Kelm, M.A., Nair, M.G., Strasburg, G.M. and DeWitt, D.L. (2000) Antioxidant and cyclooxygenase inhibitory phenolic compounds from Ocimum sanctum Linn. Phytomedicine. 7: 7-13.

Pattanayak, P., Behera, P., Das, D. and Panda, S.K. (2010) Ocimum sanctum Linn. A reservoir plant for therapeutic applications: An overview. Pharmacognosy Reviews. 4: 95-105.

Rastogi, S., Kalra, A., Gupta, V., Khan, F., Lal, R.K., Tripathi, A.K., Parameswaran, S., Gopalakrishnan, C.,
Ramaswamy, G. and Shasany, A.K. (2015) Unravelling the genome of Holy basil: an "incomparable" "elixir of life" of traditional Indian medicine. BMC Genomics. 16: 413.

Shishodia, S., Majumdar, S., Banerjee, S. and Aggarwal, B.B. (2003) Urosolic acid inhibits nuclear factor-kappaB activation induced by carcinogenic agents through suppression of IkappaBalpha kinase and p65 phosphorylation: Correlation with down-regulation of cyclooxygenase 2 , matrix metalloproteinase 9, and cyclin D1. Cancer Research. 63: 4375-83.

Singh, N. and Hoette, Y. (2002) Tulsi: The Mother Medicine of Nature. Lucknow, India: International Institute of Herbal Medicine.

Upadhyay, A.K., Chacko, A.R. et al., (2015) Genome sequencing of herb Tulsi (Ocimum tenuiflorum) unravels key genes behind its strong medicinal properties. BMC Plant Biology. 15: 212.

\section{How to cite this article:}

Manish Kumar Suthar, V. Thondaiman, Parmeshwar Lal Saran and Manish Kumar Mittal. 2019. Development of Liquid Nitrogen Free and Efficient DNA Isolation Method for Plants Rich in Volatile Oil, Secondary Metabolites and Polysaccharides. Int.J.Curr.Microbiol.App.Sci. 8(12): 2412-2418. doi: https://doi.org/10.20546/ijcmas.2019.812.283 